\title{
Innovation and Research in Education: A Necessary Tandem for the 21st Century
}

\author{
Enric Mallorquí-Ruscalleda \\ California State University, Fullerton, CA, USA \{emallorq@fullerton.edu\} \\ Recieved on 20 Juny 2015; revised on 20 June 2015; accepted on 30 June 2015; published on 15 July 2015 \\ DOI: $10.7821 /$ naer.2015.7.138
}

Currently, immersed, as we live, in the Internet Galaxy, which goes far beyond the power of connectivity between author/source of knowledge and reader/receptor, educational research cannot leave aside both research and innovation. On the one hand, it is intended to generate knowledge and to move forward with the application that ICT (information and communications technology) offers in order to improve our reality and knowledge of it. On the other hand, it is necessary to not victimize ourselves when considering the prodigious mirage that ICT can have, since we cannot forget that, in fact, the final goal is the field of Education. With it, and keeping in mind that our objective is to bring Education to excellence, we must direct our research towards innovation, and not only focusing on novel aspects... We are dwarfs who need to jump on cyclopean giants' shoulders such as the classics of Education, since their efficacy has been more than proved. However, this cyclopean base must not be limited to the unique and, as such, limited vision of the Cyclop. We must expand our perspective, but, at the same time, acceot that some pedagogical methods simply do not really contribute to innovation, and they therefore do not help to better understand our reality.

To this noble goal we devote this special issue that I now have the pleasure to present and that the always rigurous and dynamic NAER embraces. This edited volume is titled "Innovation as Valuable Catalyst Element of Educational Reseach”. The first section contains four well-documented articles on flexible learning itineraries based on conceptual maps (Olga Lucía Agudelo, Jesús Salinas); early childhood student teachers' observations and experimentation of creative practices as a design process (Janaina Minelli, Eliana E. Gargallo-Echenique); the impact of a cooperative learning program on the academic achievement in Mathematics and Language in fourth grade students and its relation to cognitive approach (Mery Luz Vega, Christian Hederich); and virtual worlds and social and educational inclusion in a case study (Lida Castañeda et al.).

The miscellaneous section embraces other no less rigorous essays that analyze many other aspects, highlighting the new trends of this interdisciplinary study: integration processes of a Romanian group in a Huelva village through family life (Antonia-María Días-Reales, Ignacio Aguaded); inclusive education in schools in rural areas (J. Antonio Callado et al.); professional development in teacher digital competence and improvement in school quality from the teachers' perspective (Mercè Gisbert, José L. Lázaro); online tutoring procedures for supervision of research project (Antònia Darder, Adolfina Pérez); school organization and the mobilization of teachers and students in the use of a new general secondary education curriculum in East Timor (Ana Capelo, Isabel Cabrita).

When it comes to performing educational research, and more specifically when seeking educational innovations, one must emphasize the concrete (in other words, on specific cases) that is then projected towards the general. Following with another Classical metaphor we could remember that Theseus, after killing the ferocious Minotaur, is able to escape from the unicursal labyrinth thanks to Ariadne's thread; this allowed Theseus to obtain a new becoming that was waiting for him outside of the labyrinth. That thread and the wise devotions of Ariadne, along with the proper decisions taken by Theseus are the keys, and not only the metaphor, of the necessary and inextricable relationship between the microcosms and the macrocosms, between the research of the concrete and its relevance to the whole, along with the indispensable interdisciplinary cooperation among researchers for the innovation of quality and highly productive research outcomes.

Enric Mallorquí-Ruscalleda California State University, Fullerton, CA, USA 